ROCZNIKI FILOZOFICZNE

Tom LXVII, numer $2-2019$

DOI: http://dx.doi.org/10.18290/rf.2019.67.2-2

\title{
GRZEGORZ WITOLD SALAMON
}

\author{
POZNANIE, JAKIM DYSPONUJE DUSZA \\ ODDZIELONA OD CIAŁA PO ŚMIERCI, \\ WEDŁUG BŁ. JANA DUNSA SZKOTA \\ NA PODSTAWIE ANALIZY ORDINATIO IV \\ D. 45 (XIV 135-197)
}

W 2013 r., po 75 latach prac Komisji Szkotystycznej, ukazał się ostatni, czyli czternasty tom głównego dzieła bł. Jana Dunsa Szkota określanego w wydaniu krytycznym mianem Ordinatio (w wydaniu Wadding-Vivés nazywano je Opus Oxoniense) ${ }^{1}$. Oprócz czternastu tomów Ordinatio do tej pory wydanych zostało także sześć tomów Lectura (dalej będzie używany skrót: Lect.), które są notatkami do wykładów Dunsa Szkota. Oba te dzieła są Komentarzami do Sentencji Piotra Lombarda, z tym że Ordinatio, jako tekst przejrzany, uporządkowany i przygotowany do publikacji przez samego Doktora Subtelnego, cieszy się większym autorytetem niż Lectura. Do naszych czasów nie zachował się niestety tekst Lectura IV (komentarz do czwartej księgi Sentencji Piotra Lombarda). Ordinatio IV jest więc w tej chwili jedyną wersją Szkotowego komentarza do czwartej księgi Sentencji Piotra Lombarda, jakim dysponujemy w wydaniu krytycznym ${ }^{2}$.

Dr Grzegorz Witold Salamon OFM — od 1.10.2007 członek Komisji Szkotystycznej do wydania krytycznego Opera omnia bł. Jana Dunsa Szkota, od 10.01.2018 Zastępca Przewodniczącego tejże Komisji (Vice-Presidente della Commissione Scotista); adres do korespondencji: Via Merulana 124B, Collegio S. Antonio, 00185 Roma, Italia; e-mail: salamon@antonianum.eu; ORCID: https://orcid.org/0000-0001-9886-7646.

${ }^{1}$ Chodzi o publikację: IOANNIS Duns SCOTI Ordinatio liber quartus: a Distinctione quadragesima tertia ad quadragesima nonam [Ord. IV d. 43-49], Opera Omnia, t. XIV, Studio et cura Commissionis Scotisticae ad fidem codicum edita, fratribus OFM P. Barnaba Hechich, Iosepho Percan, Stephano Recchia, Saturnino Ruiz De Loizaga, Vitoldo Salamon, et Hieronymo Pica, F.I. (Civitas Vaticana: Typis Vaticanis, 2013). Dalej cytowane skrótowo: Ord. IV d. ... n. ... (XIV + strona).

${ }^{2}$ W przygotowaniu jest wydanie krytyczne Reportata Parisiensia Dunsa Szkota, które obejmuje notatki z wykładów Doktora Subtelnego na ten sam temat. Prace te są prowadzone przez 
Ostatni tom Ordinatio Szkota zawiera kwestie poświęcone rzeczom ostatecznym (de novissimis). $\mathrm{Z}$ tej problematyki pragnę wybrać i poddać analizie kwestie dotyczące poznania, jakim dysponuja zbawieni $\mathrm{w}$ niebie, zawarte w dystynkcji 45 czwartej księgi Ordinatio. Ściśle rzecz biorąc, chodzi tu o sytuację poznawczą duszy oddzielonej od ciała (anima separata) w odniesieniu do: 1) istot rzeczy (quiditates) znanych jej przed oddzieleniem od ciała, 2) zdobywania nowego poznania czegoś nieznanego jej przedtem, 3) przypominania sobie przeszłych zdarzeń i rzeczy z życia ziemskiego i 4) poznania modlitw, które zanosimy do zbawionych w niebie. Te cztery sytuacje poznawcze duszy oddzielonej od ciała są przedmiotem poszczególnych kwestii analizowanych przez Doktora Subtelnego w tym miejscu (Ord. IV d. 45). Najszerzej zostanie zanalizowana kwestia trzecia, ze względu na jej obszerność (28 stron w wydaniu krytycznym) oraz ze względu na ważkość poruszanej problematyki (pamięć o zdarzeniach jednostkowych i rzeczach poznanych w ziemskim życiu) i, co jest z tym związane, ze względu na obszerną literaturę przedmiotu. Celem artykułu będzie więc przedstawienie poglądów Szkota w kwestiach wyżej wymienionych na podstawie analizy tekstów z Ordinatio IV d. 45, wraz z próbą ich interpretacji w świetle aktualnej literatury przedmiotu. W sposób szczególny zostaną uwzględnione innowacje wprowadzone przez Szkota do arystotelesowskiej epistemologii.

tzw. Komisję Amerykańską, niezależną od Komisji Szkotystycznej w Rzymie. Przewidziane jest tam także wydanie czwartej księgi Komentarza do Sentencji, ale przyjdzie na to jeszcze poczekać, gdyż do tej pory nie ukazał się żaden tom Reportata Parisiensia w wydaniu krytycznym. Do tej pory opublikowano jedynie następujące fragmenty Reportationes Szkota: 1) Klaus RoDLER, „Die Prologe der Reportata Parisiensia des Johannes Duns Scotus. Untersuchungen zur Textüberlieferung und kritische Edition”, w: Mediaevalia Oenipontana, vol. 2 (Innsbruck: Studia Universitätsverlag, 2005) (jest to wydanie krytyczne); 2) Joachim Ronald SöDER, „Kontingenz und Wissen. Die Lehre von den futura contingentia bei Johannes Duns Scotus”, w: Beiträge zur Geschichte der Philosophie und Theologie des Mittelalters. Neue Folge. T. 49 (Münster: Aschendorff Verlag, 1999) (na s. 225-265 Söder publikuje wydanie krytyczne Reportatio I A d. 38-40, a na s. 267-270 transkrypcje Reportatio I A d. 43 q. 2 oraz d. 44 q. 2 z manuskryptu M Oxford Merton 59, f. 184r-186r); 3) Johannes Duns Scotus, Reportatio Parisiensis I 38-44. Pariser Vorlesungen uiber Wissen und Kontingenz (Lateinisch, Deutsch), herausgegeben, übersetzt und eingeleitet von Joachim R. Söder (Freiburg im Breisgau: Herder, 2005) (jest to wydanie oparte głównie na manuskrypcie M Oxford Merton College 59, f. 171r-186r, który według Autora zawiera najlepszy tekst - zob. s. 31); 4) JoHn Duns Scotus, The Examined Report of the Paris Lecture: Reportatio I-A, Latin Text and English Translation, translated and edited by Allan B. Wolter and Oleg V. Bychkov (St. Bonaventure, N.Y.: Franciscan Institute, 2004), (T. 1), 2008 (T. 2) (zawiera Prolog i d. 1-48); 5) John Duns Scotus, The Report of the Paris Lecture: Reportatio $I V$ - $A$. Latin and English, edited and translated by Oleg V. Bychkov and R. Trent Pomplun (St. Bonaventure, N.Y.: The Franciscan Institute Publications, 2016), (T. 1, part 1-2) (zawiera dystynkcje 1-17). Pozycje wymienione w punktach 4) i 5) nie są wydaniami krytycznymi; są to transkrypcje jednej z wersji Reportata, czyli Reportatio A, oparte na kilku manuskryptach. 
Duns Szkot używa w tym kontekście zamiennie pojęć „dusza oddzielona [od ciała]” (anima separata) i ,intelekt” (intellectus), ponieważ według niego różnica między duszą i jej władzami - intelektem i wolą - jest różnicą formalną, mającą podstawę w naturze rzeczy (distinctio formalis ex natura rei), nazywaną częściej przez samego Szkota jako nietożsamość formalna (nonidentitas formalis) $)^{3}$. Chodzi więc o różnicę w ramach jednej bytowości, jaką jest w tym wypadku dusza ludzka, między pozytywnymi realnościami formalnymi (formalitates), którymi są tu intelekt i wola. To intelekt spełnia funkcje poznawcze w duszy, czyli poznaje; ale też i duszy jako całości możemy przypisać poznanie i powiedzieć, że dusza poznaje. W ten sposób - zamiennie jest to stosowane w omawianych kwestiach przez Doktora Subtelnego.

\section{PROBLEM POZNANIA PRZEZ DUSZĘ ODDZIELONĄ OD CIAŁA ISTOT RZECZY (QUIDITATES), KTÓRE BYŁY JEJ ZNANE W ŻYCIU ZIEMSKIM (Ord. IV d. 45 q. 1).}

Zgodnie ze sposobem omawiania zagadnień w kwestii scholastycznej Duns Szkot przedstawia najpierw argumenty przeciwne (quod non), przytaczając $\mathrm{w}$ pierwszym rzędzie wypowiedzi Arystotelesa z dzieła $O$ duszy (De anima). Całe ludzkie poznanie, według niego, ma swój początek w poznaniu zmysłowym. Dane zmysłowe poruszają zmysły, prowadząc do wytworzenia wyobrażeń zmysłowych (phantasmata), które z kolei oddziałują na intelekt i poruszają go do wytworzenia aktów poznania intelektualnego (intellectiones). W stanie jednak duszy oddzielonej od ciała wyobrażenia zmysłowe nie będą pełnić tej funkcji wzbudzania poznania zmysłowego, a potem intelektualnego, a więc nie będzie tam poznania intelektualnego jako zakotwiczonego w zmysłach ${ }^{4}$.

Podobny jest również argument z pierwszego rozdziału De anima Arystotelesa: po zniszczeniu tego, od czego wewnętrznie zależy poznanie intelektualne, zniszczony jest również intelekt. Tym, od czego wewnętrznie (interius) zależy poznanie intelektualne, jest wyobraźnia zmysłowa (organum phantasiae), która podlega zniszczeniu w momencie śmierci, co powoduje, w takim ujęciu, zniszczenie samego intelektu ${ }^{5}$.

\footnotetext{
${ }^{3}$ Cf. Roman MAJERAN, „Różnica formalna (distinctio formalis) jako narzędzie rozumienia bytu", w: Blogosławiony Jan Duns Szkot 1308-2008. Materiały Międzynarodowego Sympozjum z okazji 700-lecia śmierci bt. Jana Dunsa Szkota, Katolicki Uniwersytet Lubelski Jana Pawła II, 8-10 kwietnia 2008, red. Edward Iwo Zieliński OFMConv i Roman Majeran (Lublin: Wydawnictwo KUL, 2010), 179-182.

${ }^{4}$ Cf. Ord. IV d. 45 n. 3 (XIV 135).

${ }^{5}$ Cf. Ord. IV d. 45 n. 4 (XIV 135).
} 
Poza tym poznaje jedynie intelekt możnościowy (bierny), a nie intelekt czynny. Intelekt bierny nie będzie istniał po śmierci, jak podaje Stagiryta w trzecim rozdziale De anima. Stąd po śmierci nie będzie możliwe poznanie intelektualne ${ }^{6}$.

$\mathrm{Na}$ poparcie pozytywnej odpowiedzi omawianej kwestii przytoczone są również trzy argumenty odwołujące się do autorytetów:

1) Stwierdzenie z trzeciej księgi De anima Arystotelesa o tym, że dusza jest miejscem, w którym znajdują się formy poznawcze (species) i że właściwością miejsca jest zachowanie tego, co się w nim znajduje; stąd wniosek, że rozum zachowuje w sobie formy poznawcze także w stanie duszy oddzielonej od ciała ${ }^{7}$.

2) To, co jest przyjmowane, przyjmowane jest w tym, co przyjmuje zgodnie z naturą tego, co przyjmuje - to zasada zaczerpnięta z piątej księgi O pocieszeniu, jakie daje filozofia Boecjusza. Ponieważ dusza, przyjmująca formy poznawcze, jest niezniszczalna, dlatego przyjmuje te formy poznawcze (species) jako niezniszczalne (incorruptibiliter) ${ }^{8}$.

3) Awicenna w De anima (VI Naturalium) twierdzi, że dusza oddzielona od ciała będzie jaśniej widzieć prawdę niż dusza złączona z ciałem ${ }^{9}$. W takiej sytuacji, jeśli na ziemi możemy poznawać istoty rzeczy, to tym bardziej będziemy je mogli poznawać w stanie wolnym od materii (anima separata), jeżeli mamy wtedy jaśniej poznawać prawdę.

W swoim rozwiązaniu kwestii Duns Szkot najpierw twierdzi, że obok zmysłowych form poznawczych (species sensibiles) należy przyjąć istnienie intelektualnych form poznawczych (species intelligibiles), które pozostają w intelekcie na sposób stałej sprawności (habitus) po ustaniu wszelkich aktów poznawczych. Forma poznawcza nie jest tym samym, co stała sprawność poznawcza (habitus), ale ją poprzedza ${ }^{10}$. Do tego, aby intelekt mógł być podmiotem tych form poznawczych, nie jest wymagane, aby był on połączony z ciałem; to połączenie $\mathrm{z}$ ciałem nie jest warunkiem koniecznym ,zakorzenienia" form poznawczych w intelekcie. Formy poznawcze mogą więc występować w intelekcie oddzielonym od ciała ${ }^{11}$.

${ }^{6}$ Cf. Ord. IV d. 45 n. 5 (XIV 135-136).

${ }^{7}$ Cf. Ord. IV d. 45 n. 6 (XIV 136).

${ }^{8}$ Cf. Ord. IV d. 45 n. 7 (XIV 136).

${ }^{9}$ Cf. Ord. IV d. 45 n. 8 (XIV 136).

${ }^{10}$ Cf. Ord. IV d. 45 n. 12 (XIV 138): „Unde ex probatis ibi supponitur hic: primo quod species intelligibilis sit ponenda, - secundo, quod ipsa remanet in intellectu cessante omni actu intelligendi, nec tantum remaneat ut raptim transiens, sed ut habitus quoad rationem permanentiae. An autem sit habitus, tactum est ibi, quia loquendo de habitu usitate pro aliqua qualitate inclinante ad faciliter considerandum, species non est habitus, sed praecedit eum, immo praecedit actum a quo generatur ille habitus proprie dictus".

${ }^{11}$ Cf. Ord. IV d. 45 n. 15 (XIV 138): ,in intellectu, ut est subiectum speciei intelligibilis, non est per se requisitum - nec necessario - coniunctio eius ad corpus". 
Duns Szkot wyprowadza z tego wniosek, że forma poznawcza może w ten sam sposób wzbudzić akt poznania w intelekcie połączonym $\mathrm{z}$ ciałem i w intelekcie oddzielonym od ciała. W obu wypadkach mamy do czynienia $\mathrm{z}$ tak samo doskonałym rodzajem pamięci (memoria perfecta), która jest dana dzięki formie poznawczej i która umożliwia wzbudzenie aktu poznawczego $\mathrm{w}$ intelekcie oddzielonym od ciała, podobnie jak to było w stanie ziemskim $^{12}$. Przedmiotem tego poznania są istoty rzeczy (quiditates), czyli przedmioty ogólne. Taki rodzaj poznania jest właściwy intelektowi zgodnie $\mathrm{z}$ arystotelesowską zasadą intellectus est universalium (intelekt poznaje przedmioty ogólne). Wiedza, której cechą wrodzoną jest niezniszczalnośćc ${ }^{13}$, przechowywana jest dzięki formom poznawczym reprezentującym przedmioty ogólne.

Odpowiedź Dunsa Szkota na pierwsze pytanie postawione w tej dystynkcji jest zatem twierdząca: dusza oddzielona od ciała, dzięki formie poznawczej, która w niej pozostaje, może aktualnie poznawać istoty rzeczy (quiditates), które poznała w stanie złączenia $\mathrm{z}$ ciałem $^{14}$. Dusza $\mathrm{w}$ stanie po śmierci może sama $\mathrm{z}$ siebie aktualizować poznanie przedmiotów, które zna w stały sposób (habitualiter), czyli jest w przygodnej możności do aktualnego poznania tych przedmiotów ${ }^{15}$.

\section{POZNANIE CZEGOŚ NOWEGO}

PRZEZ DUSZĘ ODDZIELONĄ OD CIAŁA (Ord. IV d. 45 q. 2).

W zamyśle Dunsa Szkota chodzi tu o odpowiedź na pytanie o zdolności poznawcze intelektu pozbawionego połączenia z ciałem po śmierci. Pojawia się więc pytanie o możliwość poznania bez zapośredniczenia w ciele, czyli bez odwołania się do doświadczenia zmysłowego. Jeśli taki sposób poznania intelektualnego byłby możliwy, to będzie możliwe także poznanie przedmio-

\footnotetext{
${ }^{12}$ Cf. Giovanni Pizzo, Intellectus und memoria nach der Lehre des Johannes Duns Scotus. Das menschliche Erkenntisvermögen von Spontaneität und Rezeptivität (Kevelaer: Verlag Butzon \& Bercker, 1998), 139-149.

${ }^{13}$ Cf. Ord. IV d. 45 n. 17 (XIV 140): ,Scientia autem ex parte sui nata est incorruptibiliter manere”.

${ }^{14}$ Cf. Ord. IV d. 45 n. 16 (XIV 139-140): „Ex hoc habeo quod species intelligibilis eodem modo potest informare intellectum separatum sicut coniunctum. [...] sequitur quod in intellectu separato poterit esse memoria eiusdem rationis cum illa quae fuit in coniuncto [...]; ergo anima separata - per speciem intelligibilem retentam cuiuscumque cuius prius potuit - poterit habere actualem intellectionem".

${ }^{15}$ Cf. Ord. IV d. 45 n. 17 (XIV 140): „Igitur anima separata est in potentia accidentali ad intelligendum obiecta sibi habitualiter nota; ergo potest ex se exire in actum”.
} 
tów nowych, czyli takich, których intelekt nie znał w stanie ziemskim. W kwestii pierwszej chodziło o możliwość „przechowania” wiedzy nabytej w życiu ziemskim w życiu po śmierci; w kwestii drugiej chodzi natomiast o rozpatrzenie możliwości nabycia nowego poznania w życiu pozagrobowym, czyli przez duszę oddzieloną od ciała. Jest to zatem pytanie natury filozoficznej o możliwości poznawcze umysłu, ale także natury teologicznej, bo dotyczy stanu człowieka po jego naturalnej śmierci. Zakładana tu jest wiara w życie pozagrobowe, która dla bł. Jana Dunsa była pewnikiem wypływającym z Objawienia.

Pierwszym argumentem przytoczonym przeciwko takiej możliwości jest odwołanie się do daremności połączenia duszy z ciałem, jeżeli dusza także bez połączenia z nim mogłaby poznawać nowe przedmioty. Dusza jako forma nie łączy się z ciałem ze względu na doskonałość ciała, tylko na odwrót, tzn. materia łączy się z formą ze względu na doskonałość formy. Ciało więc, łącząc się z duszą, nabywa możliwość nabywania wiedzy dzięki pośrednictwu zmysłów. To zapośredniczenie poznania w zmysłach byłoby niepotrzebne, gdyby dusza oddzielona od ciała również mogła nabywać nową wiedzę ${ }^{16}$.

Druga przesłanka przeciwna odwołuje się do konieczności przyjęcia jakiegoś pośrednika (medium), dzięki któremu byłoby możliwe przejście od danych ze świata materialnego do intelektu, który jest natury duchowej; w tym pośredniku przedmioty są częściowo natury materialnej i częściowo natury niematerialnej ${ }^{17}$. W czasie życia ziemskiego takim pośrednikiem między światem materialnym i niematerialnym $\mathrm{w}$ procesie poznania są zmysły. $\mathrm{W}$ poznaniu zmysłowym wydobywa się z rzeczy zmysłowej formy poznawcze (species sensibiles), które na dalszym etapie procesu poznawczego sa przekształcone $\mathrm{w}$ intelektualne formy poznawcze (species intelligibiles). W ten sposób przechodzi się od ujęcia przedmiotów jednostkowych przez zmysły do poznania przedmiotów ogólnych, które jest domeną intelektu według klasycznego ujęcia arystotelesowskiego ${ }^{18}$.

Jeżeli zaś, wbrew stanowisku empiryzmu genetycznego, byłoby możliwe poznanie jakiegoś przedmiotu nieznanego wcześniej duszy oddzielonej od ciała, to wtedy mogłaby ona poznać jakikolwiek nieznany sobie wcześniej przedmiot i oddalenie od takiego przedmiotu nie uniemożliwiałoby jego poznania. Wydaje się to sprzeczne z poglądem św. Augustyna o tym, że dusze

\footnotetext{
${ }^{16}$ Cf. Ord. IV d. 45 n. 35 (XIV 146).

${ }^{17}$ Cf. Ord. IV d. 45 n. 36 (XIV 147): „Item, transitus ab extremo in extremum non potest esse nisi per medium; res extra est omnino materialiter, in intellectu omnino immaterialiter; ergo oportet quod transeat per medium, in quo aliquo modo sit materialiter et aliquo modo imamterialiter".

${ }^{18}$ Cf. Aristoteles, Physica, I, t. 49 (AL VII ${ }^{1.2}$ s. 26, w. 4-5; A c. 5, 189a 7-8): „ratio quidem universalis est, sensus autem particularis".
} 
oddzielone od ciała nie poznają tego, co dzieje się na ziemi, chyba że dowiedzą się o tym od aniołów lub dusz zmarłych, którzy do nich przychodząa ${ }^{19}$.

Na poparcie tezy o możliwości poznania nowych przedmiotów przez dusze oddzieloną od ciała Szkot powołuje się na opinię św. Jana Damasceńskiego o tym, że natura nie może być pozbawiona swojego specyficznego działania. Właściwą operacją duszy, która jest najdoskonalszą formą, jest trojakie działanie: poznanie - w odniesieniu do intelektu możnościowego, abstrakcja w odniesieniu do intelektu czynnego i chcenie - w odniesieniu do woli. Żaden sposób bytowania duszy, który jest jej właściwy, nie może uniemożliwić jej wykonywania tych operacji wypływających z jej natury. Możliwość istnienia duszy w stanie oddzielonym od ciała wypływa z jej natury, dlatego także w tym stanie dusza może poznawać, abstrahować i chcieće ${ }^{20}$.

Jako „opinia innych” (opinio aliorum) jest przedstawione stanowisko św. Tomasza z Akwinu, które podkreśla najpierw konieczność odpowiedniości, zgodności (convenientia) między przyjmującym i przyjmowanym. Owa odpowiedniość jest możliwa dzięki formie poznawczej w zmysłach, gdyż jest ona niematerialna podobnie jak intelekt, a $z$ drugiej strony jest przedstawieniem uwarunkowań materialnych rzeczy zewnętrznych. W poznaniu duszy oddzielonej od ciała nie będzie zmysłowych form poznawczych, a tym samo będzie brakowało tej odpowiedniości między przyjmującym (dusza oddzielona od ciała) i przyjmowanym (pojęcia rzeczy materialnych wcześniej jej nie znane). Tym samym należałoby wykluczyć możliwość nabywania nowych pojęć przez duszę oddzieloną od ciała ${ }^{21}$. Z drugiej jednak strony, według tego stanowiska, poznanie $\mathrm{w}$ stanie duszy oddzielonej od ciała będzie możliwe dzięki wpływowi istot wyższych, czyli Boga i aniołów ${ }^{22}$.

${ }^{19}$ Cf. Ord. IV d. 45 n. 37 (XIV 147).

${ }^{20}$ Cf. Ord. IV d. 45 n. 38 (XIV 147-148): ,Anima autem humana est perfectissima forma, et eius propria operatio secundum intellectum possibilem est intelligere, secundum agentem abstrahere, secundum voluntatem velle; ergo nullus modus essendi potest convenire animae secundum naturam suam in quo non possit in istas operationes. Secundum autem naturam suam, talis est quod potest habere esse separatum, et hoc est ex perfectione naturae suae (unde non convenit aliis formis imperfectis); ergo in illo 'esse' potest in istas operationes".

${ }^{21}$ Cf. Ord. IV d. 45 n. 40 (XIV 148): „Arguit enim quod 'oportet esse quamdam convenientiam inter recipiens et receptum; species autem in sensibus exsistentes habent convenientiam cum intellectu in quantum sunt sine materia, et cum rebus materialibus in quantum sunt cum condicionibus materialibus; et ideo convenienter sensus recipit a rebus materialibus, et intellectus a sensu, - non autem intellectus immediate a rebus materialibus', quia non est ibi talis convenientia".

${ }^{22}$ Cf. Ord. IV d. 45 n. 41 (XIV 148): „Quomodo igitur intelliget? Dicunt quod 'per influentiam a superioribus substantiis, a Deo videlicet vel ab angelis, - et hoc loquendo de naturali influentia et naturali cognitione eius". 
Po rozpatrzeniu w sposób bardzo szczegółowy wszystkich racji i odrzuceniu tezy przeciwnej (w n. 45-61) Duns Szkot przedstawia swoje stanowisko. Jego odpowiedź na pytanie postawione w tej kwestii jest pozytywna, czyli że dusza oddzielona od ciała może poznać przedmiot wcześniej nieznany, i to w sposób zarówno abstrakcyjny, jak i intuicyjny ${ }^{23}$.

Do poznania w sposób abstrakcyjny wymagane jest, aby element aktywny, czyli działanie intelektu, oraz element pasywny, czyli rzecz (przedmiot), były wobec siebie w relacji odpowiedniości, proporcjonalności, która jest dana przez jakiś pośrednik poznawalny intelektualnie (chodzi tu praktycznie o species) i obecny w rzeczy. Takie wystarczające zbliżenie (proporcjonalność) zachodzi między intelektem duszy oddzielonej od ciała a rzeczą (np. kamieniem) i dlatego może nastąpić skutek, jakim jest poznanie abstrakcyjne przedmiotu wcześniej nieznanego. Intelekt czynny razem z przedmiotem jest wystarczającą przyczyną aktywną intelektualnej formy poznawczej (species intelligibilis). W konkretnym poznaniu zmysłowym (phantasma) nie ma nic takiego, bez czego nie byłoby możliwe wytworzenie intelektualnej formy poznawczej. Intelekt możnościowy, w ujęciu Szkota, jest do tego stopnia receptywny (receptivus), że może przyjąć nowe poznanie intelektualne, nawet przy braku wcześniejszego poznania zmysłowego ${ }^{24}$.

Warunkami poznania intuicyjnego są natomiast przedmiot obecny w jego aktualnym istnieniu oraz intelekt czynny oraz bierny ${ }^{25}$. Wszystkie te warunki mogą występować w naszym przypadku. Wyobrażenie zmysłowe (phantas$m a)$ nie wystarcza do wzbudzenia poznania intuicyjnego, dlatego że to wyobrażenie może reprezentować przedmiot zarówno obecny, jak i nieobecny wobec podmiotu poznającego; stąd nie możemy mieć dzięki takiemu wyobrażeniu poznania rzeczy jako istniejącej w jej aktualnym istnieniu ${ }^{26}$. Takie

${ }^{23}$ Cf. Ord. IV d. 45 n. 62 (XIV 156-157): „Ad quaestionem igitur dico quod anima separata potest acquirere cognitionem obiecti prius ignoti, et hoc tam cognitionem abstractivam quam intuitivam".

${ }^{24}$ Cf. Ord. IV d. 45 n. 63-64 (XIV 157). Rozróżnienie na intelekt czynny i bierny (możnościowy), charakterystyczne dla filozofii średniowiecznej, traci swoje znaczenie w koncepcji Dunsa Szkota, jak to zaznacza Walter Hoeres w Die Sehnsucht nach der Anschauung Gottes. Thomas von Aquin und Duns Scotus im Gespräch über Natur und Gnade (Aachen: PatrimoniumVerlag 2015), 16. Powodem tego jest zaakcentowanie wewnętrznej jedności aktu poznawczego.

${ }^{25}$ Cf. Ord. IV d. 45 n. 65 (XIV 157-158). Definicje poznania intuicyjnego w ujęciu Dunsa Szkota oraz jego cechy charakterystyczne są podane w sposób syntetyczny w: Grzegorz Witold SAlamon, Koncepcja poznania intuicyjnego u Jana Dunsa Szkota (Niepokalanów: Wydawnictwo Ojców Franciszkanów, 2007), 77-78.

${ }^{26}$ Cf. Ord. IV d. 45 n. 65 (XIV 158): „Et ita, ut videtur, probatur quod necesse est rem ipsam immediate sufficere ad cognitionem intellectualem habendam de ipsa. quia solum phantasma non 
poznanie rzeczy w jej aktualnym istnieniu może być także poznaniem intelektualnym, a nie tylko zmysłowym jak to było w koncepcji arystotelesowskiej, bo inaczej intelekt nie miałby pewności o istnieniu jakiegokolwiek przedmiotu $^{27}$.

Rozwiązanie zaproponowane przez Szkota jest zatem bardziej intelektualistyczne w porównaniu z koncepcją Arystotelesa. Nawet bez ujęcia zmysłowego umysł może bowiem poznać istoty rzeczy (quiditates) w sposób zarówno abstrakcyjny, jak i intuicyjny.

\section{MOŻLIWOŚĆ PRZYPOMNIENIA SOBIE}

PRZEZ DUSZĘ ODDZIELONĄ OD CIAŁA KONKRETNYCH ZDARZEŃ I RZECZY POZNANYCH W ŻYCIU ZIEMSKIM (Ord. IV d. 45 q. 3).

Problematyka tutaj poruszana dotyczy koncepcji pamięci (memoria, recordatio), jaką przedstawił Jan Duns Szkot i była ona przedmiotem pogłębionych analiz badaczy zajmujących się myślą Doktora Subtelnego ${ }^{28}$.

sufficit ad cognitionem intuitivam obiecti, quia phantasma repraesentat rem exsistentem vel nonexsistentem, praesentem vel non-praesentem, - et per consequens per ipsum non potest haberi cognitio de re ut exsistente, in propria exsistentia praesente". Zob. także: Michal CHABADA, Cognitio intuitiva et abstractiva. Die ontologischen Implikationen der Erkenntnislehre des Johannes Duns Scotus mit Gegenüberstellung zu Aristoteles und I. Kant (Mönchengladbach: B. Kühlen Verlag, 2005), 90-91.

${ }^{27}$ Cf. Ord. IV d. 45 n. 65 (XIV 158): „Talis autem cognitio, quae dicitur 'intuitiva', potest esse intellectiva, alioquin intellectus non esset certus de aliqua exsistentia alicuius obiecti".

${ }^{28}$ Najważniejsze publikacje na ten temat: 1) Giovanni Pizzo, Intellectus und memoria nach der Lehre des Johannes Duns Scotus. Das menschliche Erkenntisvermögen als Vollzug von Spontaneität und Rezeptivität, Veröffentlichungen der Johannes-Duns-Akademie für franziskanische Geistesgeschichte und Spiritualität, T. 7 (Kevelaer: Verlag Butzon \& Bercker, 1998); 2) Giovanni PIzzo, „Natura e funzione della memoria: il percorso scotiano tra Agostino e Aristotele”, w: Via Scoti. Metodologica ad mentem Ioannis Duns Scoti. Atti del Congresso Scotistico Internazionale Roma 9-11 marzo 1993, red. Leonardo Sileo (Roma: Edizioni Antonianum, 1993), 525-560; 3) Alexander Söllinger, Erkenntnistheoretische Implikationen der Memoria-Konzeption von Scotus, W: Via Scoti. Metodologica ad mentem Ioannis Duns Scoti. Atti del Congresso Scotistico Internazionale Roma 9-11 marzo 1993, red. Leonardo Sileo (Roma: Edizioni Antonianum, 1993), 483-493; 4) Allan B. Wolter \& Merilyn AdAms McCord, „Memory and Intuition: A Focal Debate in Fourteenth Century Cognitive Psychology", Franciscan Studies 53 (1993): 173-230 (zawiera thumaczenie angielskie Ord. IV d. 45 q. 3); 5); Dominik Perler, „Gibt es eine Erinnerung nach dem Tod? Zur methodologischen Funktion der post mortem-Argumentation in der spätmittelalterlichen Erkenntnistheorie", w: Miscellanea Mediaevalia. Veröffentlichungen des Thomas-Instituts der Universität zu Köln, T. 29: Ende und Vollendung. Eschatologische Perspektiven im Mittelalter, red. Jan A. Aertsen i Martin Pickavé (Berlin, New York: Walter de 
Najbardziej szczegółową analizę interesującej nas kwestii przedstawił Dominik Perler w swoim artykule z 2002 r. (zob. przypis 28). Jak słusznie zauważa ${ }^{29}$, Duns Szkot, odwołując się do Arystotelesa, rozpoczyna od wskazania dwóch argumentów przemawiających przeciwko możliwości przypominania sobie przez duszę oddzieloną od ciała tego, co znała w stanie połączenia z ciałem: 1) władza przypominania należy do części zmysłowej duszy, a nie do części intelektualnej ${ }^{30}$; 2) władza pamięci odnosi się do konkretnych warunków przedmiotu jako istniejącego, chociaż w przeszłości, stąd nie może nią dysponować intelekt, który ujmuje to, co ogólne ${ }^{31}$. Aby więc dać możliwość przypominania sobie czegoś z czasu ziemskiego życia przez sam intelekt po śmierci, należy zmodyfikować teorię opartą na koncepcji Arystotelesa. Zanim jednak Szkot to uczyni, przedstawia jeszcze argumenty teologiczne za i przeciw.

Jeśli dusza po śmierci miałaby pamiętać wszystkie fakty z życia ziemskiego, to musiałaby też pamiętać o popełnionych grzechach. Wniosek wypływający $z$ tego stwierdzenia wydaje się fałszywy, albowiem w rozdziale 65 księgi proroka Izajasza czytamy: „Oto ja stwarzam nowe niebiosa” (w. 17) oraz „dawne udręki pójdą w zapomnienie” (w. 16); poza tym św. Grzegorz twierdzi, że zbawieni w niebie nie będą odczuwali żadnego nieszczęścia, żadnej biedy, a pamięć o grzechach wzbudzałaby z pewnością brak zadowolenia i smutek ${ }^{32}$.

Jako argument za tezą pozytywną Szkot przedstawia słowa Abrahama do bogacza z przypowieści o ubogim Łazarzu i bogaczu: „Wspomnij, synu, że za życia otrzymałeś swoje dobra, a Łazarz przeciwnie, niedolę"33. Za posiadaniem pamięci o faktach z życia ziemskiego przemawiają też słowa psalmu 108: „Na wieki będę wysławiał miłosierdzie Pana” wraz z komentarzem św. Grzegorza, że miłosierdzie Boże mogę uwielbiać tylko wtedy, gdy pamiętam o swojej nędzy ${ }^{34}$. Te argumenty teologiczne za i przeciw będą rozważone pod koniec kwestii trzeciej, po rozstrzygnięciu zasadniczego pytania dotyczącego pamięci w części intelektualnej duszy.

Gruyter, 2002), 448-464; 6) Camille BÉRuBÉ, La connaissance de l'individuel au Moyen Age (Montréal, Paris: Presses de l'Université, Presses Universitaires, 1964), 193-202.

${ }^{29}$ Cf. Perler, „Gibt es eine Erinnerung nach dem Tod?”, 450.

${ }^{30}$ Cf. Ord. IV d. 45 n. 76 (XIV 162).

${ }^{31}$ Cf. Ord. IV d. 45 n. 77 (XIV 162-163).

${ }^{32}$ Cf. Ord. IV d. 45 n. 78 (XIV 163). Cytaty z Pisma św. za Biblią Tysiąclecia.

${ }^{33}$ Łk 16, 25. Cf. Ord. IV d. 45 n. 79 (XIV 163).

${ }^{34}$ Cf. Ord. IV d. 45 n. 81 (XIV 164). 
Duns Szkot uważa, za Arystotelesem, że akty przypominania sobie odwołują się do aktów ujęcia zmysłowego, ale obrazy ujęte w poznaniu zmysłowym nie stanowią przedmiotu aktów przypomnienia. Akty przypominania sobie mają, według niego, podwójny przedmiot: przedmiot bliższy (obiectum proximum), którym jest ujęcie czegoś w przeszłości, oraz przedmiot dalszy (obiectum remotum et ultimum), którym jest sama rzecz lub zdarzenie, do którego odnosi się ujęcie z przeszłości ${ }^{35}$. Nie chodzi tu o zupełnie oddzielone od siebie przedmioty, bo pierwszy przedmiot nie jest różny od drugiego, a tylko określa sposób, w jaki ten drugi przedmiot jest przypominany, czyli określa sposób (modus) przedstawienia drugiego przedmiotu ${ }^{36}$. Szkot precyzuje też, że można mieć akt przypomnienia dotyczący tylko swojego własnego aktu z przeszłości, a nie dotyczący przypomnienia przez kogoś innego, gdyż tylko w ten sposób, dzięki bezpośredniemu aktowi przypomnienia, w którym ujęty jest przedmiot bliższy, może być poznany przedmiot dalszy aktu przypomnienia, którym jest sama rzecz, do której odnosi się przypomnienie ${ }^{37}$.

Przy całej tej analizie trzeba pamiętać, że odnosi się ona do poznania na poziomie zmysłów, takiego zaś poznania, a co się z tym wiąże - pamięci zmysłowej, nie będzie miała dusza oddzielona od ciała po śmierci. Przy założeniu zatem, że dysponujemy pamięcią (memoria, recordatio) tylko na poziomie zmysłowym, odpowiedź na pytanie postawione w tej kwestii musiałaby być negatywna. Duns Szkot jednak idzie dalej i rozważa możliwość przechowywania wspomnień z czasu ziemskiego życia przez część intelektualną duszy po śmierci ${ }^{38}$.

Jak to zwykle bywa, Duns Szkot rozpoczyna od przywołania autorytetu Arystotelesa, według którego zapamiętujemy przynajmniej niektóre przedmioty ujęte w poznaniu intelektualnym, jak np. że suma kątów w trójkącie równa jest dwom kątom prostym ${ }^{39}$. Zgodnie $\mathrm{z}$ arystotolesowskim poglądem empiryzmu genetycznego wszelkie poznanie intelektualne ma swoje źródło w zmysłach. Także i to ujęcie intelektualne trójkąta musiało być w jakiś sposób związane z jakimś wcześniejszym ujęciem przez zmysły. Intelekt wydobywa ze zmysłów to, co jest ogólne w rzeczach, i przechowuje to w formie inte-

\footnotetext{
${ }^{35}$ Cf. Perler, „Gibt es eine Erinnerung nach dem Tod?”, 450-451. Zob. tekst Dunsa Szkota: Ord. IV d. 45 n. 94 (XIV 167).

${ }^{36}$ Cf. Perler, „Gibt es eine Erinnerung nach dem Tod?”, 451.

${ }^{37}$ Cf. Ord. IV d. 45 n. 96 (XIV 168).

${ }^{38}$ Zob. Ord. IV d. 45 n. 117-146 (XIV 174-184).

${ }^{39}$ Cf. Ord. IV d. 45 n. 117 (XIV 174-175).
} 
lektualnej formy poznawczej (species intelligibilis). Owa forma poznawcza należy do sfery intelektualnej, a więc nie „ginie” w chwili śmierci człowieka. Problem polega jednak na tym, że takie formy poznawcze muszą być natury ogólnej (zgodnie z tezą arystotelesowską), a więc nie przechowują wspomnień konkretnych faktów i rzeczy jednostkowych poznanych w życiu ziemskim. Duns Szkot wprowadza w tym punkcie pewne innowacje i uważa, że dusza ludzka po śmierci dysponuje także wspomnieniami o zdarzeniach jednostkowych. Innowacje te dotyczą rozumienia intelektualnej formy poznawczej i jej powstawania oraz roli poznania intuicyjnego $\mathrm{w}$ tym procesie. Przyjrzyjmy się bliżej tym dwom zagadnieniom.

Jeśli chodzi o formy poznawcze w rozumieniu Dunsa Szkota, to Dominik Perler wyróżnia trzy elementy, które są ważne przy określeniu tego, czym one są. Po pierwsze, nie są to jakieś obrazy przechowywane w naszym wnęt$\mathrm{rzu}$, ale są to bytowości, które mają strukturę pojęciową. Po drugie, intelekt przypomina sobie coś za pomocą takiego pojęcia, ale samo to pojęcie nie jest przedmiotem przypomnienia, lecz jest nim to, do czego to pojęcie się odnosi. Po trzecie, Duns Szkot nie twierdzi, że pamięć intelektualna jest jedynym rodzajem pamięci; dysponujemy, według niego także pamięcią zmysłową (memoria sensitiva), którą posiadają ludzie i zwierzęta ${ }^{40}$.

Problematyce intelektualnej formy poznawczej, pamięci intelektualnej oraz ich roli w procesie poznania poświęcone są trzy pierwsze kwestie trzeciej części w trzeciej dystynkcji księgi pierwszej dwóch najważniejszych Szkotowych komentarzy do Sentecji Piotra Lombarda, czyli Ordinatio i Lectura $^{41}$, oraz kwestie czwarta, piąta i szósta dystynkcji trzeciej w pierwszej księdze Reportata parisiensia ${ }^{42}$. Ogólnie rzecz biorąc, Duns Szkot akceptuje

\footnotetext{
${ }^{40}$ Cf. PERLER, „Gibt es eine Erinnerung nach dem Tod?”, 453-454.

${ }^{41}$ Chodzi o Ord. I d. 3 pars 3 q. 1-3 n. 333-568 (III 201-338) oraz Lect. I d. 3 pars 3 q. 1-3 n. 249-426 (XVI 325-395). Ten skrótowy sposób cytowania tekstów Szkota odnosi się do następujących tomów wydania krytycznego: 1) IOANNIS Duns Scoti Opera omnia, t. III (Ord. I d. 3), ed. Carolus Balić, Martinus Bodewig, Stanislaus Bušelić, Petrus Čapkun-Delić, Barnabas Hechich, Ioannes Jurić, Bruno Korošak, Lucas Modrić, Ioseph Montalverne, Sebastianus Nanni, Faustinus Prezioso, Iulius Reinhold, Odulfus Schäfer (Civitas Vaticana: Typis Polyglottis Vaticanis, 1954); 2) IoAnNis Duns SCOTI Opera omnia, t. XVI (Lect. Prol. et d. 1-7), ed. Carolus Balić, Martinus Bodewig, Stanislaus Bušelić, Petrus Čapkun-Delić, Barnabas Hechich, Ioannes Jurić, Bruno Korošak, Lucas Modrić, Sebastianus Nanni,Iulius Reinhold, Odulfus Schäfer (Civitas Vaticana: Typis Polyglottis Vaticanis, 1960).

${ }^{42}$ Cf. John Duns Scotus, The Examined Report of the Paris Lecture. Reportatio I-A, t. 1, 207-243 (pełna informacja bibliograficzna w przypisie 2). Wydanie Wading-Vivés nie zawiera pierwszej i drugiej księgi Reportata parisiensia Dunsa Szkota (skopiowano tam Additiones magnae Wilhelma z Alnwick, jak o tym czytamy w artykule: Barnaba $\mathrm{HeCHICH,} \mathrm{„Il} \mathrm{problema} \mathrm{delle}$
} 
pogląd tomistyczny, że intelektualna forma poznawcza (species intelligibilis) jest formalną zasadą poznania ${ }^{43}$ oraz - podobnie jak św. Tomasz z Akwinu - uznaje, że ta forma poznawcza nie jest dostępna w pełni dla intelektu w bezpośrednim kontakcie z rzeczą, ale „dochodzi się” do niej za pośrednictwem poznania zmysłowego i na drodze abstrakcji ${ }^{44}$. Doktor Subtelny przyjmuje pogląd o odciśnięciu formy poznawczej (impressio speciei) w intelekcie możnościowym, co gwarantuje ważną rolę przedmiotu poznania (czyli rzeczy) w procesie poznania intelektualnego ${ }^{45}$. Ów proces odciśnięcia podobieństwa poznawczego jest ściśle natury kognitywnej, a nie organicznej (jak uważał Henryk z Gandawy) $^{46}$. Samo poznanie (intellectio) Duns Szkot określa jako „ruch rzeczy do duszy” (motus rei ad animam) ${ }^{47}$. Świadczy to o jego realizmie teoriopoznawczym, czyli przeświadczeniu, że intelekt może poznać rzeczywistość taka, jaka ona jest, a sam proces poznania jest rozumiany jako „odpoznanie rzeczywistości”.

Po przedstawieniu tej krótkiej charakterystyki intelektualnej formy poznawczej oraz samego procesu poznania (intellectio) w ujęciu Dunsa Szkota przejdźmy do odpowiedzi, jaką daje on na pytanie o pamięć w części intelektualnej duszy:

Mówię więc [...], że w [części] intelektualnej jest pamięć i akt przypomnienia we właściwym tego słowa znaczeniu. Zakładamy bowiem, że intelekt nie tylko poznaje przedmioty ogólne [...], ale także intuicyjnie poznaje te [przedmioty], które poznaje

'Reportationes' nell'eredità dottrinale del B. Giovanni Duns Scoto, OFM', w: Giovanni Duns Scoto. Studi e ricerche nel VII Centenario della sua morte, red. Martin Carbajo Nuñez (Roma: Edizioni, Antonianum, 2004), 75). Należy zatem odwoływać się do wydania Woltera-Bychkova aż do momentu ukazania się wydania krytycznego, które jest przygotowywane w USA.

${ }^{43}$ Cf. Leen SPRUIT, Species intelligibilis. From Perception to Knowledge, t. 1: Classical Roots and Medieval Discussions (Leiden, New York, Köln: E. J. Brill, 1994), 259.

${ }^{44}$ Cf. ibid., 264.

${ }^{45}$ Cf. Ord. I d. 3 n. 382 (III 232-233): ,responedeo quod obiectum respectu potentiae primo habet praesentiam realem, videlicet approximationem talem ut possit gignere talem speciem in intellectu, quae est ratio formalis intellectionis; secundo, per illam speciem genitam, quae est imago gignentis, est obiectum praesens sub ratione cognoscibilis seu repraesentati. Prima praesentia praecedit naturaliter secundam, quia praecedit impressionem speciei per quam est formaliter secunda praesentia... Et intelligo sic, quod in primo signo naturae est obiectum in se vel in phantasmate praesens intellectui agenti, in secundo signo naturae - in quo ista sunt praesentia intellectui possibili, ut agentia passo - gignitur species in intellectu possibili, et tunc per speciem est obiectum praesens sub ratione cognoscibilis".

${ }^{46}$ Cf. Spruit, Species intelligibilis, 264.

${ }^{47}$ Cf. Ord. I d. 3 n. 387 (III 235): ,intellectio etiam sequens impressam speciem, est motus rei ad animam, quatenus per intellectionem obiectum habet 'esse' in anima actualiter cognitum, quod prius tantum habuit 'esse' habitualiter". 
zmysł (ponieważ doskonalsza i wyższa władza poznawcza odnośnie do tego samego przedmiotu poznaje to, co niższa [władza poznawcza]), a także poznaje dane zmysłowe (a obu tych twierdzeń dowodzi się w ten sposób, że [intelekt] poznaje prawdziwe sądy przygodne i z nich wnioskuje; formowanie zatem zdań oraz wnioskowanie przysługuje intelektowi; a więc prawda tych sądów orzekana jest o przedmiotach jako ujętych intuicyjnie, mianowicie ze względu na istnienie, i pod tym względem są [one] poznawane przez zmysły). Z tego wnioskuje się, że w intelekcie występują wszystkie określone wcześniej warunki 'przypominania sobie': może zatem ujmować czas i posiadać akt [przypomnienia] po czasie oraz pozostałe [warunki] ${ }^{48}$.

Odpowiedź Dunsa Szkota jest zatem twierdząca. Elementem, który rozwiązuje przedstawione wcześniej trudności dotyczące pamięci o rzeczach i zdarzeniach jednostkowych, jest poznanie intuicyjne, którym dysponuje intelekt i które dotyczy tych samych przedmiotów, które ujmuje władza zmysłowa (chodzi oczywiście o przedmioty jednostkowe). Są one poznawane w ten sposób, że intelekt na poziomie prostego oglądu (simplex apprehensio) ujmuje jednocześnie całość (simul totum), czyli istotę rzeczy (quiditas) i jej aktualne istnienie $^{49}$. Jeśli rzecz jest obecna w swoim istnieniu realnym wobec intelektu, to mamy do czynienia, według Szkota, z doskonałym poznaniem intuicyjnym. Natomiast niedoskonałe poznanie intuicyjne, w rozumieniu Doktora Subtelnego, ma za przedmiot rzecz ujętą w przeszłości (memoria de praeterito) albo jest opinią o przyszłych faktach (opinio de futuro) ${ }^{50}$.

Żeby więc intelekt mógł przywołać wspomnienie o jakimś jednostkowym zdarzeniu z przeszłości, musi ono być w jakiś sposób przechowywane nie

${ }^{48}$ „Dico igitur [...] quod in intellectiva est memoria et actus recordandi proprie dictus. Supposito enim quod intellectus non tantum cogoscat universalia [...], sed etiam intuitive cognoscat illa quae sensus cognoscit (quia perfectior et superior cognoscitiva in eodem cognoscit illud quod inferior) et etiam quod cognoscat sensationes (et utrumque probatur per hoc quod cognoscit propositiones contingenter veras, et ex eis syllogizat; formare autem propositiones, et syllogizare est proprium intellectui; illarum autem veritas est de obiectis ut intuitive cognitis, sub ratione scilicet exsistentiae, sub qua cognoscuntur a sensu), - sequitur quod in intellectu possunt inveniri omnes condiciones prius dictae pertinentes ad 'recordari': potest enim percipere tempus, et habere actum post tempus, et sic de ceteris". Ord. IV d. 45 n. 136-137 (XIV 180-181).

${ }^{49}$ Cf. SAlamon, Koncepcja poznania intuicyjnego u Jana Dunsa Szkota, 147-148 oraz Ludger HonNEFELDER, „Ens inquantum ens. Der Begriff des Seienden als solchen als Gegenstand der Methaphysik nach der Lehre des Johannes Duns Scotus", w: Beiträge zur Geschichte der Philosophie und Theologie des Mittelalters. Neue Folge, T. 16 (Münster: Aschendorff, 1989), 252. $\mathrm{W}$ obu przywołanych publikacjach podane są odwołania do tekstów samego Szkota, które potwierdzają ten pogląd.

${ }^{50}$ Cf. Ord. III d. 14 n. 111 (IX 467). Zob. również SALAmON, Koncepcja poznania intuicyjnego u Jana Dunsa Szkota, 40-41. Tekst Szkota jest cytowany z: IOANNIS Duns Scoti Opera omnia, t. IX (Ord. III d. 1-17), ed. Barnabas Hechich, Benedictus Huculak, Ioseph Percan, Saturnino Ruiz de Loizaga (Civitas Vaticana: Typis Vaticanis, 2006). 
tylko w pamięci zmysłowej, ale również intelektualnej. W tym miejscu Ordinatio Duns Szkot mówi, że w intelekcie pozostają doświadczenia i wspomnienia poszczególnych przedmiotów, rzeczy poznanych aktem doskonałego poznania intuicyjnego $^{51}$ i że we władzy pamięci pozostaje forma poznawcza (species) różna od tej, z którą mamy do czynienia w poznaniu abstrakcyjnym $^{52}$. W Lectura precyzuje on natomiast, że poznanie, jakim dysponuje władza pamięci, jest tożsame $\mathrm{z}$ poznaniem intuicyjnym niedoskonałym, które $\mathrm{z}$ kolei jest tym, co pozostaje po poznaniu intuicyjnym doskonałym ${ }^{53}$. Jeżeli więc we władzy pamięci pozostaje forma poznawcza (species) rzeczy ujętej w doskonałym akcie poznania intuicyjnego i pamięć, o której mowa, jest tożsama $\mathrm{z}$ niedoskonałym poznaniem intuicyjnym, to wynika $\mathrm{z}$ tego, że w niedoskonałym poznaniu intuicyjnym mamy do czynienia $\mathrm{z}$ formą poznawczą (species). O potrzebie species, która jest odciśnięta we władzy pamięci w momencie realnej obecności przedmiotu wobec intelektu poznającego, mówi Szkot również w interesującej nas w tym punkcie kwestii trzeciej z Ord. IV d. $45^{54}$. I tu pojawia się problem, ponieważ w wielu innych miejscach dzieł Doktora Subtelnego intelektualne poznanie intuicyjne określane jest jako rodzaj poznania bezpośredniego, czyli pozbawionego formy poznawczej (species) ${ }^{55}$.

Reinhold Messner proponuje tutaj rozwiązanie, które wydaje się wielce prawdopodobne, a mianowicie że Szkot używa w tym kontekście słowa species $\mathrm{w}$ innym sensie. Świadczy o tym stwierdzenie, że species jest odciśnięta w pamięci w trakcie jej intelektualnego ujęcia, a nie że jest uprzednia wobec

${ }^{51}$ Cf. Ord. III d. 14 n. 115 (IX 469): ,de talibus pluribus, perfecte intuitive cognitis, derelicta sunt plura experimenta et plures memoriae in intellectu".

${ }^{52}$ Cf. Ord. III d. 14 n. 116 (IX 470): ,de re praesente non tantum derelinquitur species intelligibilis in intellectu qua cognoscitur sub nulla differentia temporis, sed alia (supple: species derelinquitur) in potentia memorativa”. Słowa w nawiasie zostały przejęte z aparatu krytycznego $\mathrm{T}$ (testimonia) w wydaniu krytycznym na tej samej stronie.

${ }^{53}$ Cf. Lect. III d. 14 n. 153 (XX 353-354): „Unde cognitio ista memorativa est intuitiva imperfecta, derelicta ex cognitione intuitiva perfecta". Tekst ten jest cytowany z: IOANNIS DUNS Scoti Opera omnia, t. XX (Lect. III d. 1-17), ed. Barnabas Hechich, Benedictus Huculak, Ioseph Percan, Saturnino Ruiz de Loizaga, Caesar Saco Alarcón (Civitas Vaticana: Typis Vaticanis, 2003).

${ }^{54}$ Cf. Ord. IV d. 45 n. 95 (XIV 167): „,cum oporteat potentiam recordativam habere speciem, et hoc loquendo de tota integra requisita ad recordationem, non posset illa imprimi ab obiecto quando non est vel quando non est praesens; illud autem obiectum proximum est actus humanus praeteritus, - ergo dum ille fuit, imprimebatur species necessaria”.

${ }^{55}$ Dyskusji na temat species intelligibilis w poznaniu intuicyjnym jest poświęcony osobny punkt w cytowanej już monografii na ten temat poznania intuicyjnego u Szkota (zob. SALAMON, Koncepcja poznania intuicyjnego u Jana Dunsa Szkota, 116-136). Są tam również przytoczone teksty Szkota na ten temat. Autor przychyla się do zdania tych interpretatorów myśli Szkota, którzy wykluczają species z obszaru poznania intuicyjnego (S. Day, Bèraud de Saint Maurice, L. Honnefelder). 
aktualnego aktu poznania intelektualnego jako jego przedmiot. Species w takim rozumieniu nie są pojęciowo ujętymi przedmiotami $\mathrm{w}$ intelekcie biernym, ale są „śladami w pamięci” (Gedächtnisspuren), dzięki którym te obrazy poznawcze są „odświeżane” przez intelekt ${ }^{56}$.

Słowa Dunsa Szkota na temat obecności species w pamięci intelektualnej (zob. przypisy 51 i 52), tożsamej z niedoskonałym poznaniem intuicyjnym ze strony intelektu, nie pozostawiają żadnej wątpliwości. Właśnie ta species jest formą poznawczą, która pozwala nam przypomnieć sobie jednostkowe rzeczy i zdarzenia z przeszłości. Jest to jednak inna species niż ta, która jest intelektualną formą poznawczą istoty (quiditas) rzeczy w poznaniu abstrakcyjnym ${ }^{57}$. Jak zauważa Dominik Perler, przy tworzeniu species kształtowane są nie tylko pojęcia ogólne, ale także jednostkowe, które odnoszą się do jednego konkretnego przedmiotu (np. do tej konkretnej katedry w Kolonii) ${ }^{58}$. Te jednostkowe pojęcia są aktywowane, kiedy intelekt przypomina sobie jakąś konkretną rzecz lub konkretne zdarzenie z przeszłości. Trudno jednak do końca określić, jak rozumiał tę species $\mathrm{w}$ niedoskonałym poznaniu intuicyjnym sam Doktor Subtelny.

Pamięć intelektualna rozumiana jako niedoskonałe poznanie intuicyjne spełnia wszystkie cztery wymienione na początku tej kwestii warunki przypomnienia sobie czegoś z przeszłości: ujmowanie czasu, wzbudzenie aktu przypomnienia po upływie jakiegoś czasu, brak bezpośredniej obecności przedmiotu przypomnienia oraz jego uaktualnienie przez species $^{59}$. W czasie ziemskiego życia pamięć intelektualna nie jest doskonałym oglądem i potrzebuje pamięci zmysłowej za każdym razem do uaktywnienia wspomnień z przeszłości ${ }^{60}$. To właśnie pamięć w części zmysłowej duszy jest uważana przez Dunsa Szkota za bardziej źródłową, zakorzenioną i wystarczającą z siebie samej do wzbudzenia aktu przypomnienia, niż pamięć w części intelektualnej duszy ${ }^{61}$.

\footnotetext{
${ }^{56}$ Cf. Reinhold Messner, Schauendes und begriffliches Erkennen nach Duns Skotus mit kritischer Gegenüberstellung zur Erkenntnislehre von Kant und Aristoteles (Freiburg im Breisgau: Verlag Herder, 1942), s. 96.

${ }^{57}$ Cf. Honnefelder, „Ens inquantum ens. Der Begriff des Seienden”, 238; Michal CHABAdA, Ján Duns Scotus. Vybrané kapitoly z jeho epistemológie a metafizyki (Bratislava: Filosofická Fakulta Univerzity Komenského, 2007), 42.

${ }^{58}$ Cf. PERLER, „Gibt es eine Erinnerung nach dem Tod?”, 456.

${ }^{59}$ Cf. Ord. IV d. 45 n. 90-93 (XIV 166-167). Zob. także Pizzo, Intellectus und memoria, 190 oraz BÉRuBÉ, La connaissance de l'individuel au Moyen Age, 197.

${ }^{60}$ Cf. Axel SchmidT, „Intellektuele Anschauung bei Duns Scotus”, w: Franziskanische Forschungen 45 Heft: Zwischen Weisheit und Wissenschaft. Johannes Duns Scotus im Gespräch, red. Franz Lackner (Kevelaer: Verlag Butzon \& Berker, 2003), 164.

${ }^{61}$ Cf. Ord. IV d. 45 n. 132.135 (XIV 179. 180): „Aliud est quod memoria in parte sensitiva est sufficiens ad operandum sine intellectu, ut patet in brutis, sed - e converso - intellectiva
} 
Cały proces poznania thumaczący poszczególne etapy prowadzące do powstania pamięci intelektualnej w koncepcji Dunsa Szkota, można przedstawić w następujący sposób: 1) pierwszy kontakt poznawczy z rzeczą dokonuje się dzięki poznaniu intuicyjnemu na poziomie zmysłów i intelektu, a temu poznaniu na poziomie intelektu towarzyszy poznanie abstrakcyjne; 2) przedmiot ujmowany zmysłowo wzbudza we władzy wyobraźni zmysłowej obraz (zmysłową formę poznawcza), który przy współpracy z intelektem czynnym jest „przetwarzany” w intelektualną formę poznawczą (species intelligibilis) potrzebną do ujmowania natury rzeczy w poznaniu abstrakcyjnym; 3) ten sam przedmiot, czyli jakaś konkretna rzecz istniejąca lub konkretne zdarzenie, wzbudza w intelekcie akt doskonałego poznania intuicyjnego; 4) ten akt doskonałego poznania intuicyjnego pozostawia po sobie w pamięci intelektualnej jakąś species (formę poznawczą), różną od tej potrzebnej do poznania abstrakcyjnego; 5) bezpośrednim przedmiotem pamięci intelektualnej jest niedoskonałe poznanie intuicyjne zachowane dzięki species; 6) przedmiotem pośrednim pamięci intelektualnej jest sam przedmiot, do którego się odnosi, czyli jakaś konkretna rzecz lub zdarzenie z przeszłości ${ }^{62}$.

Przedmiotem pamięci intelektualnej, według Dunsa Szkota, mogą być wszystkie te przedmioty, które są przedmiotem pamięci zmysłowej, ponieważ intelekt ujmuje intuicyjnie wszystkie akty poznania zmysłowego wtedy, gdy zachodzą i przypomina je sobie po upływie jakiegoś czasu ${ }^{63}$. Oprócz tego intelekt może przypominać sobie wiele innych bezpośrednich przedmiotów poznania, które nie mogą być przedmiotem pamięci zmysłowej; do nich zaliczają się akty poznania i akty woli z przeszłości. Doktor Subtelny uzasadnia to $w$ ten sposób, że gdybyśmy nie zapamiętywali aktów poznania i decyzji woli z przeszłości, to nie moglibyśmy żałować złych decyzji podjętych kiedyś ani „przenosić” ujęcia poznawczego z przeszłości do przyszłości, a co za tym idzie - nie moglibyśmy wnioskować na podstawie tych aktów poznania z przeszłości ${ }^{64}$. W takim znaczeniu, jeśli przypominam sobie

memoria non sufficit ad operandum sine memoria sensitiva, sicut non possumus intelligere sine phantasmate. [...] Sic igitur, quantum ad primitatem vel radicabilitatem, vel sufficientiam ex se ad actum, non est memoria in parte intellectiva, sed in sensitiva, etiam in nobis".

${ }^{62}$ Cf. BÉRUBÉ, La connaissance de l'individuel au Moyen Age, 199-200. Zaproponowany tam schemat został przeze mnie doprecyzowany i nieco zmodyfikowany.

${ }^{63}$ Cf. Ord. IV d. 45 n. 138 (XIV 181): „Et potest breviter recordari cuiuscumque obiecti, cui potest memoria sensitiva recordari, quia potest illum actum — qui est proximum obiectum intuitive cognoscere quando est, et ita recordari postquam fuit".

${ }^{64}$ Cf. ibid.: ,potest etiam recordari multorum obiectorum proximorum, quorum non potest sensitiva recordari (utpote omnis intellectionis et volitionis praeteritae). Quod enim talium recor- 
prawdę o tym, że suma kątów w trójkącie wynosi $180^{\circ}$, to przypominam sobie z przeszłości konkretny czas, kiedy nauczyłem się tej prawdy, czyli sam proces uczenia się tego. Tak przypomnianą prawdę mogę zastosować np. do rozwiązania jakiegoś zadania matematycznego. Podobnie jeśli chodzi o decyzje woli zapamiętane z przeszłości - mogą one wywoływać w nas albo zadowolenie, albo żal.

W tym miejscu należy zauważyć, że błędna jest interpretacja tekstów Dunsa Szkota przedstawiona przez Douglasa C. Langstona, przypisująca zdolność do zapamiętania czegoś wyłącznie intelektualnemu poznaniu abstrakcyjnemu ${ }^{65}$. Na tę błędną interpretację Langstona zwraca uwagę Axel Schmidt $^{66}$. Według Langstona bowiem intelekt najpierw poznaje intuicyjnie jakiś istniejący przedmiot, potem wytwarza jego formę poznawczą (species intelligibilis) i następnie poznaje ten przedmiot $\mathrm{w}$ sposób abstrakcyjny dzięki tejże species ${ }^{67}$. To właśnie dzięki species, przechowującej pojęciowo ujęty przedmiot, intelekt miałby przypominać sobie akty doskonałego poznania intuicyjnego z przeszłości. Jest to jednak niemożliwe, ponieważ — według Szkotowej koncepcji - pojęcia zawierają treści ogólne ujęte niezależnie od istnienia lub nieistnienia przedmiotu i dlatego nie nadają się do tego, aby orzekać sądy egzystencjalne ${ }^{68}$. Langston wydaje się nie dostrzegać tego, że akty intelektualnego poznania intuicyjnego i abstrakcyjnego, według Dunsa Szkota, są paralelne i że dotyczą tego samego przedmiotu, ujętego w inny sposób (różny jest modus tego poznania). Nie jest więc tak, że jedno wywodzi się od drugiego, czyli poznanie abstrakcyjne z ujęcia intuicyjnego.

Po uzasadnieniu tezy o tym, że intelekt przechowuje w swojej pamięci wspomnienia konkretnych zdarzeń oraz rzeczy ujętych w przeszłości, Szkot

detur homo, probatur, quia alias non posset poenitere de malis volitionibus, nec etiam praeteritam intellectionem ut praeteritam conferre ad futuram, nec per consequens, ex eo quod ista speculatus est, ordinare se ad speculandum alia sequentia ex istis; et breviter destruuntur, si intellectionum et volitionum praeteritarum non recordamur".

${ }^{65}$ Cf. Douglas C. LANGSTON, „Scotus's Doctrine of Intuitive Cognition”, Synthese 96 (1993): $3-24$.

${ }^{66}$ Cf. SCHMIDT, „Intellektuele Anschauung bei Duns Scotus”, 165-167.

${ }^{67}$ Cf. LAngston, „Scotus's Doctrine of Intuitive Cognition”, 8-9. Ta species jest przezeń rozumiana jako medium quo, czyli pośrednik „przeźroczysty”, dzięki któremu ujmowana jest rzecz, a nie jako obiectum quod, czyli jako przedmiot ujęcia poznawczego (zob. SALAMON, Koncepcja poznania intuicyjnego u Jana Dunsa Szkota, 128-133). Jak słusznie zaznacza Walter Hoeres, species w arystotelesowskiej tradycji średniowiecznej zawsze była rozumiana jako pośrednik poznawczy (medium in quo cognoscitur), a nie jako przedmiot poznania (vide Walter HoERES, „Gradatio entis. Sein als Teilhabe bei Duns Scotus und Franz Suárez”, Editiones scholasticae 14 (2012): 211).

${ }^{68}$ Cf. SCHMIDT, „Intellektuele Anschauung bei Duns Scotus”, 166. 
idzie o krok dalej i mówi, że skoro takim poznaniem dysponuje intelekt $\mathrm{w}$ stanie połączenia $\mathrm{z}$ ciałem, to takim samym poznaniem będzie dysponował również intelekt $\mathrm{w}$ stanie oddzielonym od ciała po śmierci ${ }^{69}$. Już w odpowiedzi na pierwsze pytanie postawione w tej dystynkcji (zob. Ord. IV d. $45 \mathrm{n}$. 16) Szkot odwołuje się do zasady, że wszystkimi formami poznawczymi i operacjami z nich wynikającymi, którymi dysponował umysł złączony $\mathrm{z}$ ciałem, będzie dysponował również umysł w stanie oddzielonym od ciała po śmierci ${ }^{70}$. Natomiast pamięci zmysłowej, jako przysługującej władzy zmysłowej w sensie całościowym, nie będzie w duszy oddzielonej od ciała. Sformułowanie „w sensie całościowym” Szkot tłumaczy w ten sposób, że chodzi tu o formę całości obejmującej złożenie z duszy i ciała i dlatego, chociaż dusza jest czymś, co formalnie jest obecne we władzy zmysłowej, to jednak dusza odłączona od ciała, ujmując przedmioty natury zmysłowej, nie ujmuje ich w sensie całościowym, ponieważ brakuje tu właśnie złączenia duszy z ciałem ${ }^{71}$. Czyli dusza oddzielona od ciała będzie mogła przypominać sobie to wszystko, co było przedmiotem pamięci zmysłowej w stanie połączenia z ciałem, ale nie będzie mogła dysponować wszystkimi rodzajami przypomnienia, którymi dysponowała dusza w stanie połączenia $\mathrm{z}$ ciałem ${ }^{72}$. W stanie ziemskim sama pamięć intelektualna nie jest władzą wystarczającą do przypominania sobie rzeczy i zdarzeń jednostkowych, lecz wymagana jest do tego współpraca ze strony pamięci zmysłowej. Po śmierci jednak dusza oddzielona od ciała będzie mogła mieć te same prerogatywy przypominania sobie wyżej wymienionych przedmiotów, i to nie ze względu na jakąś dodatkową doskonałość jej przysługującą, ale ze względu na inny porządek władz poznawczych w działaniu ${ }^{73}$.

Takie jest stanowisko Dunsa Szkota w tej kwestii. Odnośnie do zastrzeżeń od strony teologicznej, że wszystkie udręki po śmierci pójdą w zapom-

\footnotetext{
${ }^{69}$ Cf. Ord. IV d. 45 n. 147 (XIV 184): „Ad quaestionem igitur patet quod cum in anima coniuncta sit aliqua memoria intellectiva, illa remanet in separata, et per consequens notitia habitualis omnium illorum quae usque ad separationem manserunt in ea".

${ }^{70}$ Cf. ibid.: ,Et per consequens potest uti illis remanentibus ad actus recordandi, sicut posset uti coniuncta, quia - ut dictum est in praecedente quaestione - omnes formae intelligibiles et operationes consequentes, quae poterant haberi a coniuncta, poterunt haberi a separata".

${ }^{71}$ Cf. ibid.: „memoria autem sensitiva, loquendo de totali potentia, non manet in separata, sicut nec aliqua potentia sensitiva. Dixi autem 'totali', quia etsi anima sit illud quod est formale in potentia sensitiva, tamen potentia sensitiva formaliter includit quamdam formam totius, compositi ex corpore sic mixto et anima perficiente proportionaliter ad actum correspondentem tali toti; et per consequens, cum recordari sensitivae sit totius, illud non potest competere animae separatae".

${ }^{72}$ Cf. Ord. IV d. 45 n. 148 (XIV 184).

${ }^{73}$ Cf. Ord. IV d. 45 n. 149 (XIV 185).
} 
nienie (Iz 65, 16) i nie będziemy odczuwali żadnego nieszczęścia, żadnej udręki (św. Grzegorz), Doktor Subtelny twierdzi, że Pan Bóg mógłby wymazać z naszej pamięci wspomnienie o grzechach popełnionych za życia ziemskiego, to jednak taka pamięć nie będzie zabrana zbawionym w niebie, bo wtedy ich udziałem byłaby jakaś szczęśliwość tylko „przypadłościowa”, powodowana tym, że radość z niewinności byłaby fałszywą radością, nieodpowiadającą prawdzie ${ }^{74}$. Pan Bóg mógłby również zachować zbawionego w niebie od aktualizacji pamięci o popełnionym grzechu przy zachowaniu stałej pamięci (memoria habitualis) o grzechu i to wykluczyłoby bliższą przyczynę smutku z powodu grzechu, ale nie przyczynę dalszą ${ }^{75}$. I wreszcie $\mathrm{w}$ celu wyeliminowania smutku powodowanego pamięcią o grzechach Szkot proponuje dwa dalsze rozwiązania: 1) Pan Bóg mógłby zawiesić naturalne przyczynowanie odnoszące się do tego, że przypomnienie grzechu powoduje smutek, ale wtedy każdorazowo trzeba by się odwołać do cudu; 2) albo należałoby powiedzieć, że naturalna przyczyna może być „unieszkodliwiona” (impediri) przez jakieś przeciwieństwo przewyższające przyczynę, i to $\mathrm{w}$ taki sposób, że przyczyna nie powoduje swojego zwyczajnego skutku; jest to możliwe zwłaszcza wtedy, gdy owo przeciwieństwo całkowicie wypełnia zdolność odczuwania, przyjmowania ${ }^{76}$. Radość wizji uszczęśliwiającej wypełnia całkowicie zdolność przyjmowania, odczuwania duszy zbawionego w niebie; dlatego nie jest on zdolny do smutku, który normalnie towarzyszy pamięci o grzechach $^{77}$. Duns Szkot przyjmuje to ostatnie rozwiązanie.

\footnotetext{
${ }^{74}$ Cf. Ord. IV d. 45 n. 157 (XIV 188): „Dico quod possibile est Deum totaliter delere a memoria beati omne peccatum; nec in hoc derogatur beato, immo videretur pertinere ad aliquam beatitudinem accidentalem eius. Si enim innocens gaudebit de sua innocentia gaudio speciali [...], licet iste non possit gaudere de innocentia, quia tunc esset eius falsum gaudium, tamen potest nocentia de memoria eius deleri ut de illa non habeat aliquam materiam tristandi"

${ }^{75}$ Cf. Ord. IV d. 45 n. 158 (XIV 188): „Potest etiam Deus, stante memoria habituali peccati commissi, praeservare beatum ne umquam exeat in actum considerandi se illud commisisse; et hoc iterum sufficeret ad excludendum occasionem proximam tristitiae, licet non remotam".

${ }^{76}$ Cf. Ord. IV d. 45 n. 159 (XIV 189): ,tunc ad vitandum tristitiam, dicendum est quod: vel Deus suspendat causalitatem illam, quam recordatio esset nata facere respectu tristitiae ]...], sed tunc est miraculum, quoties recordantur, quod non tristentur; vel si fugitur miraculum, oportet dicere quod causa naturalis potest impediri, per contrarium excellens, ne causet effectum suum, et maxime quando contrarium totaliter replet capacitatem passi"

${ }^{77}$ Cf. Ord. IV d. 45 n. 160 (XIV 189): „Ita, in proposito, gaudium de obiecto beatifico replet totaliter capacitatem beati, et ideo non est capax tristitiae, quae nata esset consequi istam recordationem".
} 


\section{PROBLEM POZNANIA PRZEZ ZBAWIONYCH W NIEBIE TREŚCI MODLITW ZANOSZONYCH DO NICH (Ord. IV d. 45 q. 4).}

W rozpatrywaniu tej kwestii należy zająć się, według Szkota, trzema problemami: 1) czy zbawieni w niebie poznają nasze modlitwy dzięki poznaniu naturalnemu, czy 2) dzięki poznaniu nadprzyrodzonemu? oraz 3) czy poznając te modlitwy, modlą się za nas? ${ }^{78}$ Dwa pierwsze pytania odnoszą się do statusu poznawczego intelektu w stanie po śmierci ciała, natomiast pytanie trzecie jest natury typowo teologicznej.

Już w kwestii drugiej analizowanej tutaj dystynkcji 45 stwierdza się, że dusza oddzielona od ciała może poznawać w sposób abstrakcyjny oraz intuicyjny, a także może ujmować przedmioty zmysłowe (jak to jest w sytuacji duszy połączonej z ciałem) oraz jakiekolwiek przedmioty poznawalne „odpowiednie" dla naszego intelektu i obecne wobec niego we właściwy sposób $^{79}$. „Odpowiedni” (proportionatum) dla umysłu w stanie po śmierci jest jakikolwiek przedmiot poznawalny stworzony, jakim jest również modlitwa wyrażona na głos słowami lub myślna zanoszona przez nas do zbawionych w niebie. Mogą oni ją poznać dzięki poznaniu intuicyjnemu, którym dysponują, jeżeli nie jest to uniemożliwione przez zbyt wielkie oddalenie od nich $^{80}$. Stwierdzenie o ,zbyt wielkim oddaleniu” jest niejednoznaczne i wydaje się, że wyklucza w praktyce poznanie naszych modlitw przez zbawionych $\mathrm{w}$ niebie ${ }^{81}$. $Z$ punktu widzenia statusu poznawczego intelektu $\mathrm{w}$ duszy oddzielonej od ciała po śmierci kluczowe jest stwierdzenie Szkota o tym, że ów umysł jest równie doskonały, albo nawet doskonalszy, od umysłu w stanie złączenia $\mathrm{z}$ ciałem ${ }^{82}$.

Odnośnie do poznania nadprzyrodzonego, którym dysponują zbawieni w niebie, Doktor Subtelny twierdzi, że nie musi w nim być zawarte ujęcie (ogląd) modlitw, jakie do nich zanosimy, ponieważ nie wypływa to wprost

${ }^{78}$ Cf. Ord. IV d. 45 n. 168 (XIV 191).

${ }^{79}$ Cf. Ord. IV d. 45 n. 169 (XIV 191): „De primo tactum est in solutione secundae quaestionis huius distinctionis, qualiter anima separata potest acquirere notitiam non solum abstractivam sed etiam intuitivam, non solum sensibilium (sicut potest coniuncta), sed etiam quorumcumque intelligibilium proportionatorum et proportionaliter praesentium".

${ }^{80}$ Cf. Ord. IV d. 45 n. 169 (XIV 191-192): „Proportionatum est sibi quodcumque intelligibile creatum; ergo orationem - sive vocalem (quam et coniuncta posset nosse per sensum corporis) sive etiam mentalem (quae tunc erit sibi proportionata) — pro tunc poterit intuitive nosse, si tamen immoderata distantia non impediat".

${ }^{81}$ Cf. Ord. IV d. 45 n. 67 (XIV 158-159).

${ }^{82}$ Cf. Ord. IV d. 45 n. 171 (XIV 192): „Intellectus autem separatus aeque perfectus est sicut intellectus coniunctus vel perfectior". 
z natury wizji uszczęśliwiającej ${ }^{83}$. Uwzględniając jednak rolę „pomocników Boga", jaką odgrywają święci w niebie, należy przyjąć jako prawdopodobne, że Pan Bóg objawia im treść modlitw zanoszonych do nich albo do samego Boga za ich wstawiennictwem; modlitwy te odwołują się do zasług świętych oraz do ich roli pośredników prowadzących do zbawienia ${ }^{84}$.

Intelekt duszy świętego w niebie może zatem poznać modlitwy do niego zanoszone, gdyż są one przedmiotem odpowiednim do poznania przez taki intelekt. Prawdopodobne jest też objawienie treści tych modlitw świętym przez Boga, jak to wyżej zaznaczono. Pozostaje jedynie pytanie: czy święty, poznawszy treść naszych modlitw, w rzeczywistości wstawia się za nami? Odpowiadając na to pytanie, Duns Szkot przedstawia pewną wątpliwość dotyczącą trzech możliwości: 1) albo zbawiony w niebie widzi, że Pan Bóg chce (velle) zbawić kogoś (wysłuchać modlitwę), i wtedy wiadomo, że będzie uratowany, a więc modli się na próżno; 2) albo widzi, że Pan Bóg nie chce (nolle) i wtedy święty nie będzie się modlił wbrew woli Bożej; 3) albo widzi, że Pan Bóg wstrzymuje się od „chcenia” (non velle) i wtedy ów święty wie, że rzecz, o którą prosiłby, nie dokona się, a więc również daremnie by się modlit ${ }^{85}$.

W odpowiedzi na tę trudność Duns Szkot mówi, że nie można przyjmować żadnej z trzech możliwości wyżej wymienionych ani wypowiadać sądów o wiecznym zbawieniu lub potępieniu tego, który zanosi modlitwę, ani też o wysłuchaniu modlitwy przez niego zanoszonej ${ }^{86}$. Pan Bóg bowiem nie objawia swojej woli świętemu, do którego zanosimy modlitwy, ze względu na to, że jeżeli Bóg chce wysłuchać czyjąś modlitwę lub kogoś zbawić, to chce to czynić dzięki pewnym środkom, do których należy również modlitwa przedstawiana za wstawiennictwem zbawionego w niebie. Ów zbawiony nie wie zatem, czy Pan Bóg chce, czy nie chce lub też wstrzymuje się od „chcenia” w odniesieniu do przedmiotu naszej modlitwy. W ten sposób święty w niebie może być pośrednikiem w modleniu się i oczekuje z nadzieją na objawienie o wysłuchaniu modlitwy albo przynajmniej na jakiś kon-

\footnotetext{
${ }^{83}$ Cf. Ord. IV d. 45 n. 174 (XIV 193).

${ }^{84}$ Cf. Ord. IV d. 45 n. 175 (XIV 193-194).

${ }^{85}$ Cf. Ord. IV d. 45 n. 176 (XIV 194). Na temat klasycznego schematu Szkotowego: velle, nolle i non velle odnośnie do absolutnej możności Boga (potentia dei absoluta) i do „trójpodziału decyzyjnego" człowieka zob: Luca PARISOLI, La contraddizione vera. Giovanni Duns Scoto tra le necessità della metafisica e il discorso della filosofia pratica (Roma: Istituto Storico dei Cappuccini, 2005), 188-196.

${ }^{86}$ Cf. Ord. IV d. 45 n. 178 (XIV 195): ,respondeo: nullum membrum oportet dare, nedum de salute finali illius qui orat, sed nec de exauditione illius orationis, quam nunc offert".
} 
kretny skutek wskazujący na wysłuchanie modlitwy, która mu została przedstawiona $^{87}$.

W ostatniej części tej kwestii Duns Szkot odpowiada na trzy argumenty przeciwne (quod non) przedstawione na początku omawianej kwestii. Pierwszy z nich odnosi się do tekstu z księgi proroka Izajasza 63, 16: „Zaiste, nie poznaje nas Abraham, Izrael nas nie uznaje". Werset ten odniesiony do interesującej nas tutaj sytuacji poznawczej jest interpretowany w następujący sposób: Abraham nie był w niebie, tylko w miejscu oczekiwania na zbawienie (limbus) i dlatego nie dysponował poznaniem Żydów w ziemi Izraela, ponieważ ze względu na oddalenie (odległość) nie mógł ich poznać w sposób intuicyjny ani nie dysponował specjalnym objawieniem ze strony Boga, gdyż nie miał udziału w wizji uszczęśliwiającej Boga, której może towarzyszyć takie objawienie; tego typu objawienie intensyfikuje szczęście doświadczane przez zbawionych w niebie albo przyczynia się do osiągnięcia szczęśliwości wiecznej przez tych, którzy są jeszcze „pielgrzymami” na ziemi ${ }^{88}$.

Drugi argument przeciwny odmawia zbawionemu w niebie możliwości poznania zanoszonych do niego modlitw ze względu na to, że tylko Pan Bóg zna tajemnice serca, do których należy modlitwa myślna ${ }^{89}$. Według Doktora Subtelnego jednak nie ma nic takiego w umyśle (chodzi tu o operacje intelektu lub woli, o ich właściwości oraz ich sposób istnienia), co nie byłoby dostępne poznawczo dla anioła lub duszy, jeśli te przedmioty są obecne we właściwy sposób, chyba że zadziała jakaś inna przeszkoda uniemożliwiająca poznanie ${ }^{90}$.

${ }^{87}$ Cf. Ord. IV d. 45 n. 178 (XIV 195): „Non enim sequitur 'Deus revelat Petro Ioannem nunc petere $a$ per merita Petri, ergo revelatur Petro Ioannem salvandum vel non salvandum', nec 'ergo revelatur Ioannem exaudiendum vel non exaudiendum in ista petitione', - tamen esto quod revelaretur sibi 'istum exaudiendum vel non exaudiendum in ista petitione', non sequitur 'ergo frustra orat', quia sicut Deus vult istum salvare vel exaudire, ita vult per determinata media (utpote per orationem talis beati) ipsum consequi. - Si autem reveletur Petro determinate quod Deus nollet istam orationem exaudire, Petrus non esset sibi mediator in orando; si vero non revelatur sibi quod velit nec quod nolit, Petrus orat exspectans ut orationem suam consequatur determinata revelatio exauditionis, vel saltem determinatus effectus exauditionis quantum ad ipsum petentem".

${ }^{88}$ Cf. Ord. IV d. 45 n. 179 (XIV 196): „Non igitur concludit de beatis, quibus in Verbo regulariter revelantur ea quae ad eos spectant: vel tamquam beatitudinem eorum augens, vel tamquam pertinens ad causalitatem eorum respectu beatitudinis aliorum" (przytoczona tu została tylko ostatnia część n. 179).

${ }^{89}$ Cf. Ord. IV d. 45 n. 165 (XIV 191): ,solus Deus novit secreta; oratio mentalis, quae maxime est Deo accepta, est huiusmodi”.

${ }^{90}$ Cf. Ord. IV d. 45 n. 180 (XIV 196): ,dico quod nihil est in mente, operatio scilicet quaecumque intellectus vel voluntatis et quaecumque proprietas vel condicio realis istius vel illius, quin totum ita pateat angelo proportionaliter praesenti non impedito, vel animae non impeditae 
Natomiast stwierdzenie o tym, że tylko Pan Bóg „zna tajniki serca” (Ps. 44, 22) jest bezwzględnie prawdziwe i odnosi się do wszystkiego, co jest zakryte i co z jakiegoś powodu (brak odpowiedniej obecności wobec poznającego lub przeszkoda ze strony Boga) nie może być poznane przez anioła dobrego lub złego, lub też przez dusze zbawionych albo potępionych (,złych”) ${ }^{91}$.

$\mathrm{W}$ trzecim argumencie przeciwnym zakłada się, że poznanie przez zbawionych w niebie zanoszonych do nich modlitw jest konieczne do tego, aby mogli się wstawiać za nami. Ale oni nie mogą się wstawiać za nami, bo nie są w stanie zasługi, a w modlitwie jako takiej jest zasługa, korzyść (meritum) ${ }^{92}$. Duns Szkot nie zgadza się z tym argumentem i twierdzi, że nasza modlitwa ma podwójny skutek: 1) jest naturalnym czynem zasługującym i stąd ma pozytywny skutek dla tego, który się modli, oraz 2) jest zanoszona za kogoś innego i dlatego pomaga (dosł. ,jest korzystna") także tej innej osobie. W odniesieniu do zbawionych w niebie chodzi oczywiście o drugi przypadek, ponieważ wstawiają się za nami $^{93}$. W ocenie Szkota nie jest czymś nieodpowiednim, aby zbawiony, który osiagnął już swój cel, czyli niebo, nie mógł przez modlitwę ,zasługiwać” na konto kogoś innego, czyli — inaczej mówiąc — sprawić, aby ktoś inny, żyjący jeszcze na ziemi, mógł stać się godny wysłuchania swojej modlitwy; Duns Szkot odwołuje się tutaj do przykładu króla, który okazuje łaskę komuś, kto nie jest tego godzien, dzięki wstawiennictwu kogoś innego, kto jest szanowany przez króla i do kogo ten król ma zaufanie ${ }^{94}$.

proportionaliter praesenti, sicut animae coniunctae per sensus apparet albedo praesens". Ta przeszkoda w poznaniu może być warunkowana ze strony Boga, jak się wydaje. Wynika to z kontekstu mówiącego o „złych”, czyli duszach potępionych, które są obecne wobec przedmiotu poznania w odpowiedni sposób, ale nie poznają tego przedmiotu ze względu na działanie uniemożliwiające to ze strony Boga (zob. przypis 91).

${ }^{91}$ Cf. Ord. IV d. 45 n. 180 (XIV 196-197): „Illud igitur dictum quod 'solus Deus novit abscondita cordium' verum est universaliter et ex propria perfectione, ita quod impossibile est quod per aliquid impediens eum lateat. Novit etiam ut Iudex universalis omnium talium occultorum, isto modo quo nec boni angeli, nec mali, nec animae separatae noverunt. Immo de facto, beati multos tales motus non noverunt propter defectum praesentiae debitae, mali autem multa talia, etiam proportionaliter praesentia, non noverunt Deo impediente, propter cuius impedimentum non possunt multa, quae tamen non impediti naturaliter possent".

${ }^{92}$ Cf. Ord. IV d. 45 n. 166 (XIV 191): „Item, non oportet eos noscere, nisi ad hoc ut orent pro nobis; sed consequens est inconveniens, quia non sunt in statu meriti; ergo non possunt orare, quia in oratione - per se - consistit meritum".

${ }^{93}$ Cf. Ord. IV d. 45 n. 181 (XIV 197): ,dico quod oratio nostra nunc duplicem habet effectum: unum, quia meritoria est oranti, immo opus naturale meritorium, — alium, quia ex hoc quod specialiter dirigitur pro alio, meritoria est illi pro quo offertur. Et primo modo beati non habent orationem, sed secundo modo".

${ }^{94}$ Cf. ibid.: „Nec est inconveniens aliquem, qui iam est in termino quoad se, per orationem suam mereri alteri, - sicut videmus in politiis: ubi rex illud quod vult dare, vult tamen per 
Podsumowując przedstawione w tym artykule analizy, można powiedzieć, że odpowiedź Dunsa Szkota na wszystkie cztery pytania postawione w poszczególnych kwestiach dystynkcji 45 w czwartej księdze Ordinatio jest pozytywna. Oznacza to, że umysł w duszy oddzielonej od ciała po śmierci może poznawać: 1) istoty rzeczy (quiditates), które były mu znane w stanie połączenia z ciałem, dzięki formie poznawczej, która w nim pozostaje także po śmierci; 2) przedmioty wcześniej mu nieznane, mimo braku poznania zmysłowego - i to w sposób zarówno abstrakcyjny, jak i intuicyjny; 3) zdarzenia i rzeczy jednostkowe ujęte przez zmysły w życiu ziemskim, dzięki specyficznej formie poznawczej (species), różnej od intelektualnej formy poznawczej (species intelligibilis), która aktualizuje konkretne poznanie z przeszłości. Takie syntetyczne odpowiedzi daje Szkot w pierwszych trzech kwestiach. W ostatniej kwestii perspektywa trochę się zmienia, bo mowa jest już nie o duszy oddzielonej od ciała (anima separata), ale o zbawionych w niebie (beati). Według Dokora Subtelnego ze względu na naturalne uposażenie intelektu zbawionych $\mathrm{w}$ niebie mogą oni poznawać treść modlitw, które do nich zanosimy.

Takie podejście do możliwości poznawczych duszy oddzielonej od ciała po śmierci jest stanowiskiem bardziej intelektualistycznym niż wizja arystotelesowska, gdyż przyznaje umysłowi większe zdolności poznawcze, nawet przy braku poznania zmysłowego. Niewątpliwie świadczy to o silnym wpływie myśli augustyńskiej na rozwiązania zaproponowane przez bł. Jana Dunsa Szkota.

\section{BIBLIOGRAFIA}

Aristoteles. Physica. Ed. F. Bossier, J. Brams (AL VII ${ }^{1.2}$ : translatio vetus). Leiden, New York: E. J. Brill, 1990.

BÉRuBÉ, Camille. La connaissance de l'individuel au Moyen Age. Montréal, Paris: Presses de l'Université, Presses Universitaires, 1964.

Chabada, Michal. Ján Duns Scotus. Vybrané kapitoly z jeho epistemológie a metafizyki. Bratislava: Filosofická Fakulta Univerzity Komenského, 2007.

HoERES, Walter. Die Sehnsucht nach der Anschaunng Gottes. Thomas von Aquin und Duns Scotus im Gespräch über Natur und Gnade. Aachen: Patrimonium-Verlag, 2015.

intercessionem alicuius dare alicui qui non esset dignus statim exaudiri, et maxime vult si aliquis (apud eum maxime acceptus) intercedat, qui tamen - acceptus - nullum gradum ulterioris amicitiae sibi meretur". 
HonNEFELDER, Ludger. „Ens inquantum ens. Der Begriff des Seienden als solchen als Gegenstand der Methaphysik nach der Lehre des Johannes Duns Scotus". W: Beiträge zur Geschichte der Philosophie und Theologie des Mittelalters. Neue Folge. T. 16. Münster: Aschendorff, ${ }^{2} 1989$.

IoANNis Duns Scoti Opera omnia. T. III (Ord. I d. 3). Ed. C Carolus Balić, Martinus Bodewig, Stanislaus Bušelić, Petrus Čapkun-Delić, Barnabas Hechich, Ioannes Jurić, Bruno Korošak, Lucas Modrić, Ioseph Montalverne, Sebastianus Nanni, Faustinus Prezioso, Iulius Reinhold, Odulfus Schäfer. Civitas Vaticana: Typis Polyglottis Vaticanis, 1954.

IoAnnis Duns Scoti Opera omnia. T. XVI (Lect. Prol. et d. 1-7). Ed. Carolus Balić, Martinus Bodewig, Stanislaus Bušelić, Petrus Čapkun-Delić, Barnabas Hechich, Ioannes Jurić, Bruno Korošak, Lucas Modrić, Sebastianus Nanni,Iulius Reinhold, Odulfus Schäfer. Civitas Vaticana: Typis Polyglottis Vaticanis, 1960.

IoANNIS Duns Scoti Opera omnia. T. XX (Lect. III d. 1-17). Ed. Barnabas Hechich, Benedictus Huculak, Ioseph Percan, Saturnino Ruiz de Loizaga, Caesar Saco Alarcón. Civitas Vaticana: Typis Vaticanis, 2003.

IoAnNis Duns Scoti Opera omnia. T. IX. Ed. Barnabas Hechich,Benedictus Huculak, Ioseph Percan, Saturnino Ruiz de Loizaga. Civitas Vaticana: Typis Vaticanis, 2006.

IoAnnis Duns Scoti Opera omnia. T. XIV (Ord. IV d. 43-49). Ed. Barnabas Hechich, Ioseph Percan, Stephanus Recchia, Saturnino Ruiz de Loizaga, Vitoldus Salamon, Hieronimus Pica. Civitas Vaticana: Typis Vaticanis, 2013.

LAnGSTON, Douglas C. „Scotus's Doctrine of Intuitive Cognition”. Synthese 96 (1993), 1: 3-24. DOI: $10.1007 / \mathrm{BF} 01063800$.

MAJERAN, Roman. „Różnica formalna (distinctio formalis) jako narzędzie rozumienia bytu”. W: Błogosławiony Jan Duns Szkot 1308-2008. Materiaty Międzynarodowego Sympozjum z okazji 700-lecia śmierci bt. Jana Dunsa Szkota, Katolicki Uniwersytet Lubelski Jana Pawła II, 8-10 kwietnia 2008, red. Edward Iwo Zieliński OFMConv i Roman Majeran. Lublin: Wydawnictwo KUL, 2010.

MESSNER, Reinhold. Schauendes und begriffliches Erkennen nach Duns Skotus mit kritischer Gegenüberstellung zur Erkenntnislehre von Kant und Aristoteles. Freiburg im Breisgau: Verlag Herder, 1942.

PARISOLI, Luca. La contraddizione vera. Giovanni Duns Scoto tra le necessità della metafisica e il discorso della filosofia pratica. Roma: Istituto Storico dei Cappuccini, 2005.

PERLER, Dominik. „Gibt es eine Erinnerung nach dem Tod? Zur methodologischen Funktion der post mortem-Argumentation in der spätmittelalterlichen Erkenntnistheorie”. W: Miscellanea Mediaevalia. Veröffentlichungen des Thomas-Instituts der Universität zu Köln. T. 29: Ende und Vollendung. Eschatologische Perspektiven im Mittelalter, red. Jan A. Aertsen i Martin Pickavé. Berlin, New York: Walter de Gruyter, 2002.

Pizzo, Giovanni. Intellectus und memoria nach der Lehre des Johannes Duns Scotus. Das menschliche Erkenntisvermögen als Vollzug von Spontaneität und Rezeptivität. Veröffentlichungen der Johannes-Duns-Akademie für franziskanische Geistesgeschichte und Spiritualität. T. 7. Kevelaer: Verlag Butzon \& Bercker, 1998.

Pizzo, Giovanni. „Natura e funzione della memoria: il percorso scotiano tra Agostino e Aristotele”. W: Via Scoti. Metodologica ad mentem Ioannis Duns Scoti. Atti del Congresso Scotistico Internazionale Roma 9-11 marzo 1993, red. Leonardo Sileo. Roma: Edizioni Antonianum, 1993.

SAlAmON, Grzegorz Witold. Koncepcja poznania intuicyjnego u Jana Dunsa Szkota. Niepokalanów: Wydawnictwo Ojców Franciszkanów, 2007.

Schmid, Axel. „Intellektuele Anschauung bei Duns Scotus”. W: Franziskanische Forschungen 45 Heft: Zwischen Weisheit und Wissenschaft. Johannes Duns Scotus im Gespräch. Red. Franz Lackner. Kevelaer: Verlag Butzon \& Berker, 2003. 
SprutT, Leen. 1994. Species intelligibilis. From Perception to Knowledge. T. 1: Classical Roots and Medieval Discussions. Leiden, New York, Köln: E. J. Brill.

Wolter, Allan B., \& Merilyn ADAMs MCCORD. „Memory and Intuition: A Focal Debate in Fourteenth Century Cognitive Psychology". Franciscan Studies 53 (1993): 175-192. DOI: 10.1353/frc.1993.0006.

\section{POZNANIE, JAKIM DYSPONUJE DUSZA ODDZIELONA OD CIAŁA PO ŚMIERCI, WEDŁUG BŁ. JANA DUNSA SZKOTA NA PODSTAWIE ANALIZY ORDINATIO IV D. 45 (XIV 135-197)}

\section{Streszczenie}

Artykuł podejmuje problematykę gnozeologiczną w odniesieniu do intelektu duszy oddzielonej od ciała w rozumieniu Jana Dunsa Szkota. Tej problematyce są poświęcone cztery kwestie w Ordinatio IV d. 45. W tej konkretnej sytuacji poznawczej jest możliwe, według Doktora Subtelnego, poznanie nowych istot rzeczy (quiditates), mimo braku poznania zmysłowego. Jest to odejście od poglądu empiryzmu genetycznego i przyznanie intelektowi większych zdolności poznawczych, niż było to w koncepcji Arystotelesa. W stanie po śmierci intelekt dysponuje również pamięcią $\mathrm{o}$ istotach rzeczy poznanych w stanie połączenia z ciałem oraz może przypominać sobie konkretne zdarzenia i rzeczy ujęte przez zmysły w ziemskim życiu. Takie ujęcie świadczy o ciagłości poznawczej intelektu ludzkiego po śmierci, o jego niezniszczalności i o zdolności poznawczej przynajmniej takiej, jaką dysponował w stanie życia ziemskiego. Widzimy tu połączenie kwestii filozoficznych i teologicznych, które wzajemnie się przenikają i warunkują. Dla Szkota możliwe jest nie tylko przypominanie sobie przeszłości oraz nabywanie nowego poznania przez intelekt duszy oddzielonej od ciała, ale również możliwe jest dla takiego intelektu poznanie modlitw zanoszonych przez nas do zbawionych w niebie. Takie intelektualistyczne podejście świadczy o silnym wpływie myśli augustyńskiej na epistemologię Jana Dunsa Szkota.

\section{THE KNOWLEDGE \\ THAT PROVIDES THE SOUL SEPARATED FROM THE BODY AFTER DEATH ACCORDING TO BLESSED JOHN DUNS SCOTUS ON THE BASIS OF ANALYSIS OF THE ORDINATIO IV D. 45 (XIV 135-197)}

\section{S u m m a ry}

The essay presents some gnoseological themes with reference to the intellect of the separated soul according to John Duns Scotus. Four questions of the Ordinatio IV, d. 45 deal with these themes. In this concret cognitive situation is possible, according to Doctor Subtilis, to get to know the new quiddities of things, in spite of a lack of the empiric cognition. It means leaving behind the conception of generic empiricism and moving to the recognition of more cognitive abilities, as in Aristoteles's conception. In a post death state (post mortem) intellect continues to have the memory of the quiddities of things known while still connected with the body and can remember concret things and events known by the senses during earthly life. Such a gnoseological notion evidences the cognitive continuity of the human intellect after death, its incorruptibility and cognitive ability at least as such as one had during earthly life. We can see here the connection of philosophic and theological questions, which mutually condition and penetrate each other. According to Scotus it is possible for the intellect of the separated soul to remember the past and to acquire new cognition. Moreover, it is also possible for such an intellect to know 
the prayers we refer to the blessed in heaven. Such an intellectual approach evidences a strong Augustinian influence on John Duns Scotus' epistemic conception.

Słowa kluczowe: Jan Duns Szkot; dusza oddzielona od ciała; poznanie; intelekt; forma poznawcza.

Key words: John Duns Scotus; soul separated from the body; cognition; intellect; intellectual species.

Information about Author: Grzegorz Witold Salamon, O.F.M., PhD - actually Deputy Chairperson of the Scotistic Commission for critical edition of the Opera Omnia of the Blessed John Duns Scotus at Antonianum in Rome; address for correspondence: Via Merulana 124B, Collegio S. Antonio, 00185 Roma, Italia; e-mail: salamon@antonianum.eu; ORCID: https:// orcid.org/0000-0001-9886-7646. 